\title{
PERENCANAAN STRATEGIS PENGEMBANGAN MINAPOLITAN (Studi di Desa Kemangi, Kecamatan Bungah, Kabupaten Gresik)
}

\author{
Adhinda Dewi Agustine \\ Dosen Program Studi Administrasi Publik, FISIP Universitas Merdeka Malang \\ email: adhinda.dewi@gmail.com
}

\begin{abstract}
Based on the Decree of the Minister of Marine Affairs and Fisheries No. 35 of 2013 on the Determination of Minapolitan Areas, Gresik Regency includes the Minapolitan area. The fishery cultivation sector of Gresik Regency has the potential to be optimized. This is supported by the sea area of Gresik Regency covering 22\% of the total area (Gresik Dalam Dalam 2015). But the problem of synergy between institutions or related agencies that play a role in running this Minapolitan Area is still not optimal. And fish farmers as subjects and objects in Minapolitan concept, have their own mindset that does not match the direction given by the Related Office.
\end{abstract}

Keyword :Strategic Planning, Developmen Planning, Minapolitan Deveelopment.

\section{PENDAHULUAN}

Indonesia merupakan sebuah Negara kepulauan yang memiliki kekayaan alam, budaya serta laut yang luar biasa. Luas perairan terbagi atas laut territorial seluas 3,2 juta km dan perairan Zona Ekonomi Eksklusif (ZEE) sebesar 2,9 juta km. Melihat kondisi geografis tersebut Indonesia memiliki potensi ekonomi kelautan yang sangat besar serta merupakan asset yang harus dimanfaatkan secara optimal melalui industri perikanan. Oleh karenanya perlu didukung dengan berbagai kebijakan program dan kegiatan pembangunan, salah satunya yaitu dengan Pengembangan Minapolitan. Minapolitan menurut Keputusan Menteri Kelautan dan Perikanan RI nomor 12 tahun 2010 adalah pembangunan ekonomi kelautan dan perikanan berbasis kawasan berdasarkan prinsip-prinsip terintegrasi, efisiensi, berkualitas dan percepatan. Penetapan Kawasan Minapolitan yang terbaru telah diatur dalam Keputusan Menteri Kelautan dan Perikanan RI nomor 39 tahun 2011 Volume 1, Nomor 2, Oktober 2016 tentang Perubahan keputusan penetapan Kawasan Minapolitan diatur pada Keputusan Menteri Kelautan dan Perikanan RI Nomor 39 tahun 2011 tentang Perubahan Jumlah Penetapan Kawasan Minapolitan, jumlah daerah Kawasan Minapolitan berubah dari 197 Kabupaten/Kota menjadi sebanyak 223 Kabupaten/Kota pada 33 Provinsi.

Pengembangan Kawasan Minapolitan sebagaimana dimaksudkan pada dictum pertama dilaksanakan secara bertahap dari tahun 2010 sampai 2014. Pelaksanaan konsep Minapolitan harus disesuaikan dengan tujuannya, yaitu peningkatan produksi, produktivitas dan kualitas untuk kesejahteraan rakyat dan pembangunan ekonomi daerah. Tentu saja dalam hal ini di perlukan pemikiran dan cara berfikir dan orientasi pembangunan dari daratan kelautan dengan gerakan yang mendasar dan cepat sesuai nilai-nilai Revolusi biru.

Minapolitan dalam sebuah perencanaan yaitu pengalokasian sumberdaya, dimana PUBLISIA (Jurnal Ilmu Administrasi Publik) $\mid 43$ 
optimalisasi pemanfaatan sumberdaya alam, manusia dan anggaran. Di dalam perencanaan pembangunan Minapolitan menjadi wilayah pengembangan dengan pendekatan pembanguanan sektoral dimana pendekatan tersebut akan memudahkan dalam menentukan sasaran yang akan dicapai dan menetapkan alokasi anggaran, dimana kebijaksanaan pembangunan dengan pendekatan perwilayahan akan mendatangkan banyak manfaat.

Konsep Minapolitan merupakan konsep yang ditawarkan oleh Friedman dan Douglas. Menurut Friedman dan Douglas dalam Anugrah (2003) Kawasan Minapolitan mempunyai konsep pola interaksi yaitu, penetapan pusat Agropolitan/Minapolitan, penetapan unit-unit kawasan pengembangan, penetapan sektor unggulan, dukungan system infrastruktur, dukungan system kelembagaan. Adanya perencanaan yang strategis mengenai pengembangan kawasan minapolitan diharapkan mampu untuk mempercepat pembangunan pedesaan dan migrasi desa ke kota dapat dikendalikan. Dukungan pemerintah diperlukan untuk melindungi kawasan minapolitan tersebut agar tidak terjadi perpindahan kepemilikan lahan dari para pelaku minapolitan kepada pihak investor asing yang tidak menjalankan proses perikanan sehinga tidak dimanfaatkan sebagaimana mestinya.

\section{KAJIAN PUSTAKA}

\section{Perencanaan; Konsep dan Terapan}

Menurut Pariata Westra (1982:26) dalam bukunya Ensklopedia Administrasi, perencanaan adalah: "Aktivitas pokok dalam manajemen yang menggambarkan hal-hal yang akan dikerjakan dan cara mengerjakannya dalam rangka mencapai tujuan yang telah ditentukan. Perkerjaaan perencanaan ini merupakan salah satu fungsi manajer, disamping fungsi - fungsi pokok lainnya, yaitu penggerakan dan pengontrolan."

Namun perencanaan dikemukakan oleh Soul M. Ketz dalam Tjokroamidjojo (1987:17), bahwa perencanaan merupakan suatu hal yang sangat penting, yaitu: a. Dengan adanya perencanaan diharapakan terdapatnya suatu pengarahan kegiatan, adanya pedoman bagi pelaksanaan bagi kegiatankegiatan yang ditujukan kepada pencapaian tujuan pembangunan. b. Dengan perencanaan maka dilakukan suatu perkiraan terhadap hal-hal dalam pelaksanaan yang akan dilalui. Perkiraan dilakukan mengenai potensipotensi dan prospek-prospek perkembangan tetapi juga mengenai hambatan-hambatan dan resiko-resiko yang mungkin 16 dihadapi. Perencanaan mengusahakan supaya ketidakpastian dapat dibatasi sedikit mungkin. c. Perencanaan memberikan kesempatan untuk memilih berbagai alternatif tentang cara yang terbaik (the best alternative) atau kesempatan untuk memiliki kombinasi cara yang terbaik (the best combinasition) $\mathrm{d}$. Dengan perencanaan dilakukan penyusunan skala prioritas, memilih urutan - urutan dari segi pentingnya suatu tujuan, sasaran maupun kegiatan usahanya. e. Dengan adanya rencana maka ada suatu alat pengukur atau standar untuk mengadakan pengawasan/kontrol. 
Memperhatikan pendapat di atas dapat ditarik pengertian bahwa perencanaan adalah suatu proses yang menghasilkan suatu rencana merupakan pemikiran-pemikiran ke depan secara matang yang mewujudkan pengambil keputusan sebagai persiapan untuk melakukan tindakan-tindakan terhadap pencapaian, tujuan tersebut dilakukan satu himpunan pengambilan keputusan.

Dalam sebuah proses perencanaan ada beberapa tahapan menurut Dusseldorp dalam Sjafrudin (1973:27), tahapan pertama yaitu rumusan masalah, dilanjut dengan pengumpulan dan pemeriksaan bahan, penyusunan rencana, penetepan rencana, dan tahapan terakhir adalah melaksanakan dan menilai hasilnya.Sedangkan menurut (Sjafrudin, 1973:44) koordinasi dalam perencanaan sangatlah penting baik di tingkat pusat aupun tingkat regional, prinsip prinsip tersebut antara lain: a. Pemerintah pusat harus menetapkan petunjuk-petunjuk tentunya melalui peraturan sebagai prosedur-prosedur dalam tahapan perencanaan. b. Pembentukan panitia-panitia gabungan local maupun regional dengan wakil-wakil lokal, regional dan pemerintah pusat dan dengan staf teknis. c. Pembentukan panitia-panitia kerja untuk menjamin terbentuknya pengertian antar ahli, seperti ahli politik, ahli teknik, dan khalayak ramai untuk menimbulkan dan melatih suasana "team spirit". d. Penggunaan media penghubung masyarakat sangat ditekankan pada setiap tahap perencanaan.

Dari penjabaran para ahli tersebut, maka dapat digariskan secara umum terdapat beberapa tahapan yang dilakukan baik melalui peraturan dan prosedur 19 yang sudah di tetapkan, dan dilakukan baik secara teknis maupun sampai ranah politik serta memperhatikan segi sosial masyarakatnya.

\section{Paradigma Pembangunan}

Siagian (1983:2) mendefinisikan Pembangunan yaitu: "suatu usaha atau rangkaian usaha pertumbuhan dan perubahan terencana yang dilakukan secara sadar oleh suatu bangsa negara dan pemerintah menuju modernitas dalam rangka pembinaan bangsa (nation building)". Pembangunan sering diartikan sebagai suatu perubahan dan merupakan sesuatu yang semestinya terjadi dalam suatu masyarakat, baik masyarakat maju maupun masyarakat sedang berkembang dan dalam perkembangannya pembangunan memiliki paradigmaparadigma didalamnya. Dimana paradigma pembangunan menurut Tjokrowinoto sebagai mana dikutip oleh Ulum (2013) pembangunan merentang mulai dari paradigma pertumbuhan, paradigma kesejahteraan, paradigma neo-ekonomi, paradigma dependensia, hingga paradigma pembangunan manusia.

Menurut Albert Waterson dalam Tjokroamidjojo (1989:12) adalah: a. Perencanaan pembangunan adalah "melihat ke depan dengan mengambil pilihan berbagai alternatif dari kegiatan untuk mencapai tujuan masa depan tersebut dengan terus mengikuti supaya pelaksaanaanya tidak menyimpang dari tujuan". b. Perencaan pembangunan adalah suatu pengarahan penggunaan sumber sumber pembangunan (termasuk sumbersumber ekonomi) yang tak 23 terbatas adanya, untuk mencapai tujuan tujuan keadaan social ekonomi yang lebih baik secara lebih efesien 
dan efektif. Proses perencanaan pembangunan dikelompokan menjadi 2 pendekatan sistem dalam proses penyusunan perencaan pembangunan yaitu dari atas ke bawah (top down planning) dan perencanaan dari bawah ke atas (bottom up planning).

Menurut Tjiptono (1997:3), secara etimologis strategis merupakan gabungan dari kata 24 stratos yang berarti militer dan ag yang berarti memimpin. Dari kedua kata tersebut tersebut dapat diartikan jika strategis merupakan ilmu atau seni untuk menjadi jenderal. Seiring perkembangan zaman istilah strategis tidak hanya digunakan pada bidang militer saja, banyak organisasi juga menggunakan istilah strategis untuk menyusun rencana dalam mencapai tujuan. Sedangkan definisi perencanaan strategis yang dikemukakan oleh Hughes dalam Riyadi dan Brantakusumah (2004, h.280) menyatakan bahwa "strategics planning is a discipline effort produce fundamental decisions, shaping the nature and direction of govermental activities, within constitutional bounds" mempunyai maksud bahwa perencanaan strategis meliputi kegiatan perumusan tindakan- tindakan penting sebagai panduan organisasi serta upaya membangun keterlibatan stakeholder dalam mewujudkan tujuan organisasi.

\section{Minapolitan: Konsep dan Pengembangan}

Konsep minapolitan pada pertengahan tahun 1970an Friedmann dalam Wiadnya (2011) mencetuskan konsep pengembangan kota kecil sebagai pusat dan ditunjang oleh beberapa wilayah desa di sekitarnya dengan sektor penggerak ekonomi dari pertanian. Teori ini dipandang sebagai solusi untuk menarik aglomerasi urban dari wilayah metropolitan. Menurut Wiadnya (2011) menyatakan minapolitan adalah proses yang dinamis dengan karakteristik dasar multisektor secara terpadu. Setiap tahapan rencana aksi dibuat melekat dengan rencana yang ada saat ini. Implementasi dari minapolitan harus selalu di evaluasi (melalui alat monitoring) untuk mengukur setiap keberhasilan atau bahkan kegagalan program. Pada proses minapolitan dibedakan menjadi dua bagian, yaitu minapolitan perikanan tangkap dan minapolitan perikanan budidaya. Kedua jenis aktifitas ekonomi ini memiliki dimensi keruangaan yang berbeda.

Berdasarkan amanat UUD 1945 pasal 33 ayat 1, 2, dan 3 maka pemerintah melalui Kementrian Kelautan dan Perikanan mengeluarkan kebijakan yang berupa Peraturan Menteri dalam rangka optimalisasi pemanfaatan sumberdaya perikanan laut maupun air tawar dengan menggunakan konsep minapolitan.Regulasi tersebut kemudian dijadikan sebagai pedoman atau landasan dalam melaksanakan program yakni Peraturan Menteri Kelautan dan Perikanan Republik Indonesia Nomer 12 tahun 2010 tentang Minapolitan dan Keputusan Menteri Kelautan dan 42 Perikanan Republik Indonesia Nomor 18 tahun 2011 tentang Pedoman Umum

Sementara itu, minapolitan dilaksanakan dengan tujuan:

a. Meningkatkan produksi, produktivitas, dan kualitas produk kelautan dan perikanan;

b. Meningkatkan pendapatan nelayan, pembudidaya ikan, dan pengolah ikan yang adil dan merata; dan 45 
c. Mengembangkan kawasan minapolitan sebagai pusat pertumbuhan ekonomi di daerah

d. Meningkatkan kemampuan ekonomi masyarakat kelautan dan perikanan skala mikro dan kecil, antara lain berupa : penghapusan dan/ atau pengurangan beban biaya produksi, pengeluaran rumah tangga dan pungutan liar, pengembangan sistem produksi kelautan dan perikanan efisien untu usaha mikro dan kecil, penyediaan dan distribusi sarana produksi tepat guna dan murah bagi masyarakat, pemberian bantuan teknis dan permodalan; dan/atau pembangunan prasarana untuk mendukung sistem produksi, pengolahan, dan/atau pemasaran produk kelautan dan perikanan.

e. Meningkatkan jumlah dan kualitas usaha kelautan dan perikanan skala menengah ke atas sehingga berdaya saing tinggi

f. f.Meningkatkan sektor kelautan dan perikanan menjadi penggerak ekonomi regional dan nasional

\section{METODE PENELITIAN}

Penelitian yang dilaksanakan ini merupakan jenis penelitian deskriptif dengan pendekatan kualitatif, dimana menurut Kirk dan Miller dalam Moleong (2009), penelitian kualitatif itu adalah tradisi tertentu dalam ilmu pengetahuan sosial yang secara fundamental bergantung pada pengamatan manusia dalam kawasannya sendiri dan berhubungan dengan orang-orang tersebut dalam bahasanya dan peristilahannya. Sedangkan Bogdan dan Taylor dalam
Moleong (2009) memberikan definisi metodologi kualitatif adalah sebagai prosedur penelitian yang menghasilkan data deskriptif berupa kata-kata tertulis atau lisan dari orangorang atau perilaku yang dapat diamati. Karakteristik lain dari penelitian kualitatif adalah penekanannya pada pandangan fenomena secara menyeluruh (holistik view) (Moleong, 2008).

\section{PEMBAHASAN}

Dinas kelautan sudah memiliki tujuan organisasi untuk di ekspresikan produk dan pelayanan yang dapat ditawarkan dan selaras dengan Keputusan Menteri No. 18 Tahun 2011 tentang pedoman umum minapolitan dimana yang memiliki misi mensejahterakan masyarakan kelautan dan perikanan. Dalam dokumen masterplan sudah dicantumkan tentang lingkungan internal eksternal, penilaian lingkungan internal eksternal yang efekif seharusnya memberikan manfaat kepada organisasi dalam menjalankan strategi minapolitan diantaranya yang terpenting adalah bahwa penilaian itu menghasilkan informasi yang sangat penting bagi kelangsungan dan kemakmuran organisasi.

Untuk menangani tantangan yang ada dalam pengembangan rencan strategis kawasan minapolitan diperlukan adanya usaha yang terpadu, beraneka ragam, terampil, penuh semangat dan juga kemitraan (partnership) efektif untuk mencapai tujuannya. Sesuai teori pemerintah Gresik dalam pelaksanaan pengembangan minapolitan sudah sesuai dengan teori yaitu dengan menerapkan 4 langkah strategi yaitu: 
a. Strategi SO (strength dan opportunities)

Strategi ini dilakukan untuk memanfaatkan kekuatan dilingkungan minapolitan guna menangkap peluang yang dimiliki lingkungan minapolitan, Pada perikanan budidaya dengan memanfaatkan sumber air yang melimpah untuk meraih hasil produksi yang optimal sesuai dengan apa yang di inginkan

b. Strategi ST (strengt dan treats)
Strategi ini diterapkan dimana kekuatan yang dimiliki lingkungan perikanan budidaya tawar digunakan untuk mengatasi ancaman yang mungkin dapat dihadapi perikanan budidaya tawar. Pemerintah dapat menyediakan pintu - pintu air untuk mengatur keluar masuk air dari saluran guna menghindari ancaman banjir yang di hasilkan oleh sungai bengawan solo dan sungai lamongan dan tidak hanya banjir tetapi juga menghindari pencemaran lingkungan yang di hasilkan dari rumah tangga dan industri berupa sampah.

\section{c. Strategi WO (weakness dan opportunities) \\ Strategi ini diterapkan pada saat adanya} peluang yang dimiliki pemerintah guna mengatasi ancaman perikanan budidaya. Pemerintah harus melakukan inovasi untuk menangkap peluang yang ada agar kualitas hasil produksi perikanan terjaga, serta melakukan berbagai normalisasi saluran tambak untuk memberikan hasil perikanan yang optimal dan memberikan penyuluhan, pelatihan dalam meningkatkan kemampuan dalam meraih modal.

\section{d. Strategi WT (weakness dan treats) \\ Strategi ini diterapkan saat pemerintah} harus mampu mengatasi kelemahan yang dimiliki lingkungan minapolitan agar terhindar dari ancaman yang akan dihadapi. Pemerintah harus mampu mencukupi cold storage,dengan menyediakan cold storage / tempat penyimpanan dengan suhu tertentu guna menjaga produk kualitas perikanan atau bertujuan mempertahankan kesegaran hasil produksi yang menjadi kekurangan dari pemerintah dalam menjaga hasil produksi perikanan.

Setelah strategi dirumuskan, tim perencanaan perlu untuk mendapatkan keputusan resmi untuk mengadopsi rencana tersebut dan melanjutkan dengan pelaksanaan. Rencana implementasi akan ditinjau secara berkelanjutan dan direvisi dengan review lima tahun seperti yang dilakukan organisasi NOAA dalam rencana strategi pendidikan. Di Desa Kemangi Kecamatan Bungah telah melakukan review strategi dengan tujuan agar saat implementasi isu yang didapat sesuai dengan strategi yang dihasilkan. Strategi yang telah dirumuskan dan tingkatkan konsensus.

Merujuk pada keputusan Menteri Kelautan dan perikanan Nomer 12 tahun 2010 yang menyebutkan bahwa "minapolitan merupakan konsep pembangunan berbasis manajemen ekonomi kawasan dengan motor pengerak sektor kelautan dan perikanan yang didasarkan pada system manajemen kawasan minapolitan serta menerapkan prinsip integrasi, efesien, kualitas dan akselerasi tinggi" berdasarkan konsep pengembangan kawasan minapolitan tersebut dengan memperhatikan komposisi personal stakeholder yang tergabung dalam tim koordinasi dan kelompok kerja pengembangan minapolitan di Kabupaten Gresik, dapat di intepretasikan bahwa 
pembangunan ekonomi masyarakat melalui konsep pengembangan kawasan minapolitan di desa kemangi kecamatan bungah tidak hanya menjadi tanggung jawab pemerintah saja, melainkan juga menjadi tanggung jawab dari setiap elemen pemangku kepentingan yang ada, yaitu pemerintah, swasta, serta masyarakat.

Didukung fasilitas, sarana dan prasarana lainnya yang mumpuni yang telah disediakan oleh Dinas Kelautan, Perikanan dan Peternakan biasanya dalam bentuk paket bantuan, paket kegiatan maupun melalui pengembangan teknologi budidaya yang bermanfaat bagi pengembangan usaha budidaya perikanan yang sangat bermanfaat bagi pengembangan usaha budidaya perikanan di Kawasan Minapolitan.Namun berdasarkan pengamatan penulisterkait pelatihan yang telah dilaksanakan dalam dukungan pengembangan kawasan minapolitan ini masih kurang merata karena adanya sistem perwakilan dari masing masing Pokdakan yang tidak semua anggota kelompok dapat menerima pemahaman yang sama. Serta pelatihan hanya fokus terkait teknis budidaya perikanan. Jadi dirasa kurang untuk mengembangkan agribisnis perikanan secara menyelurh oleh karena itu perlu adanya pelatihan tentang kewirausahaan dalam bidang produksi, manajemen keuangan, manajemen pemasaran, serta manajemen SDM pembudidaya.

\section{KESIMPULAN}

Berdasarkan hasil penelitian ini maka dapat disimpulkan, perencanaan strategi pengembangan kawasan minapolitan pada
Desa Kemangi, Kecamatan Bungah, Kabupaten Gresik, telah mendapatkan dukungan dari pemerintah daerah dengan adanya ketetapan Surat Keputusan Bupati Gresik Nomor 523/244/HK/473.12/ tahun 2011 tentang Kelompok Kerja Pengembangan Kawasan Minapolitan di Kabupaten Gresik. Kemudian diidentifikasi dengan mandat dalam membangun komitmen diantara stakeholder sebagai kunci untuk prioritas yang penting dalam mengatur pemberian pertangunggjawaban pada pihak yang memiliki wewenang dalam minapolitan.

Proses Perencanaan pengembangan kawasan minapolitan ini juga didukung oleh peran stakeholder yang mana berperan sebagai penentu kebijakan dan pengambilan keputusan dengan berkoordinir bersama Bappeda yang juga memberikan fasilitas cukup memadai yang dibutuhkan oleh kelompok sasaran pengembang kawasan minapolitan. Fasilitator yang diberikan dinas perikanan juga membantu para pembudidaya dalam menyediakan sarana prasarana serta bantuan baik dengan bentuk bantuan ataupun pelayanan yang diberikan kepada masyarakat pembudidaya dalam bentuk bantuan pelatihan - pelatihan.

\section{Saran}

Pemerintah daerah harus menjadi ketua koordinasi kebijakan yang melakukan evaluasi dan kontrol kinerja selama program harus terus berjalan untuk meminimalisir adanya tindakan menyimpang serta mengevaluasi kembali dalam perihal pemetaan wilayah minapolitan di daerah. Dikarenakan pemetaan yang ada saat ini masih belum akurat karena masih terdapat 
beberapa wilayah minapolitan yang tidak berpotensi sebagai perikanan melainkan sebagai lahan industri dan pertanian. Kemudian dalam hal perencanaan kawasan minapolitan perlu adanya regulasi yang kuat untuk kawasannya secara spesifik, dan diperlukan juga aspek pengolahan limbah perikanan, serta tempat penyimpanan hasil panen perikanan lingkungan yang bersih, agar perekonomian tetap berjalan. Hal tersebut juga perlu didukung dengan aspek kolaborasi kinerja yang baik antar staf hingga kepala dinas, dan adanya pemindahan tugas kepada pegawai yang tidak sesuai dengan bidang dan keahliannya (latar pendidikan) dihindarkan, karena hal tersebut mampu berdampak pada kurangnya motivasi para pegawai untuk melaksanakan tugas terutama dalam perihal pelaksanaan pengembanganan kawasan minapolitan didaerah.

\section{DAFTAR PUSTAKA}

Ulum, Saiful. 2013. Analisis Peran Multi Aktor dalam Implementasi Kebijakan Minapolitan berbasis Sustainable development. Malang: Fakultas Ilmu Administrasi Universitas Brawijaya.

Westra, Pariata. 1982. Ensiklopedia Administrasi. Jakarta: Balai Aksara

Wiadnya DGR, Djohani R, Erdmann MV, Halim A, Knight M, Mous Peter J, Pet Jos, Pet-Soede L. 2011. Kajian kebijakan pengelolaan perikanan tangkap di Indonesia: Menuju Pembentukan Kawasan Perlindungan Laut. JPPI. 9 (5): 1-23.

Keputusan Bupati Gresik. Nomor 523/244/HK/437.12/2011 tentang Penetapan Tim Koordinasi Dan
Kelompok Kerja Pengembangan Kawasan Minapolitan Kabupaten Gresik.

Keputusan Menteri Kelautan dan Perikanan Republik Indonesia Nomor 18 tahun 2011 tentang Penetapan Status Perlindungan Penuh Ikan Hiu Paus (Rhincodon typus)

Keputusan Menteri Kelautan dan Perikanan RI nomor 39 tahun 2011 tentang Perubahan Jumlah Penetapan Kawasan Minapolitan, adalah Kabupaten Gresik.

Undang-Undang Dasar (UUD) Negara Republik Indonesia Tahun 1945 pasal 33 tentang Pengertian Perekonomian, Pemanfaatan SDA, dan Prinsip Perekonomian Nasional 